\title{
Assessing Residents' Quality of Life in Malaysian New Towns
}

\author{
Dasimah Bt Omar \\ Faculty of Architecture, Planning and Surveying \\ Universiti Teknologi MARA \\ 40450 Shah Alam, Malaysia \\ E-mail: dasimah629@salam.uitm.edu.my
}

\begin{abstract}
One of the ultimate aims of a new town development is quality of life. This paper is based on a perception survey that was carried out to evaluate the level of quality of life experienced by the people living in 13 new towns developed by the State Economic Development Corporations in Malaysia. The analysis sought to uncover information relating to community life which was specifically planned to provide a good quality of life for its inhabitants continuously until the completion of the development. The research showed that from the indicators used in the analysis it can deduced that new towns developed by the State Economic Development Corporations were generally accepted by the residents as providing satisfying living environment. The findings of this research could be used to address the future development of new towns. The findings will be useful in determining the physical planning and quality of life indicators for sustainable development.
\end{abstract}

Keywords: Quality of life, New towns, Living environment, State Economic Development Corporations

\section{Introduction}

The planning and developing a new town is concerned with the human and social elements in relation to the built environment. Quality of life encompasses the fulfillment of all human needs such as a satisfactory standard of material life, health, education, security, the satisfaction of living in a clean environment as well as the enjoyment of the aesthetic and the spiritual. In short, it relates to the general well being of the populace. For governments the responsibility in bringing about a high quality of life is in ensuring that, inter alia, the necessary infrastructure of utilities and amenities, the institutions of social organisation and governance that permits an acceptable level of individual expression and choice, are in place. For the individual, a prerequisite of a good quality of life is an adequate income, sufficient to permit access to the facilities that the city can provide.

\section{New Town and Quality of Life}

The new model of urban residential development known as new towns was brought into the English Planning and Development concept by the 1946 and 1965 New Town Acts (Morris: 1997). New town is design to be self sufficient. After more than fifty years Howard's social cities' size proved valid when the new town committee produced a suggestion that the optimal normal range of population in a new town is between 30,000 to 50,000 people (Danang: 1997). The first generation of new town development in Britain consisted of 15 new towns with 175,000 houses, $35,000,000$ sq. $\mathrm{ft}$ of factory space, 350 schools, $4,000,000$ sq. ft. office space, 100 pubs, public buildings, several thousand acres of parks and arranged with playing fields and open space (Morris: 1997). By 1970 British followers of Howard succeeded in getting government to build new towns. The ideas also spread to United States as early as 1930. In both countries the new town experiments enjoyed modest success in providing a relatively high quality of life (Nancy: 2005). As for Hong Kong, although residential living space in new town is limited, much thought was given to enhancing the quality of life outside the home (Julie and Dinah: 2002).

The concept of "quality of life" can be a useful tool in studying and evaluating the degree of well-being and equity for living in specific circumstances (Giulietta and Paola: 1999). Milbrath (1978) states that "...if quality of life is defined as happiness or wellbeing or satisfaction, it is necessarily subjective. This is further discussed by Marans and Couper (2000). The quality of life in a particular area was a subjective phenomena and that each respondent may have different views or perceptions with regard to subject matter. The concept of "quality of life" represents more than the private "living standards" and refers to all the elements of the conditions in which people live, that is, all their needs and 
requirements. This concept has been developed by social scientists to measure and evaluate people's wellbeing, satisfaction and happiness. It demands, amongst other things, available and accessible social and public infrastructure to satisfy the needs of those involved and affected by it as well as an environment (Giulietta and Paola: 1999).

It is of theoretical interest to explore the relationship of the built environment and the satisfaction level of different living areas. Campbell, Converse and Rogers (1976) addressed the concept of quality of life as measuring the people's perceptions, evaluation and satisfaction. Leitmann (1999) listed four reasons for assessing the quality of urban life: a) to make comparisons, b) to identify problems, c) to develop policies and d) to monitor and evaluate the implementation of interventions. For many researchers satisfaction was viewed as more definable, more plausible and more appropriate to measure and compare people's assessments on quality of life experience (Marans and Couper: 2000).

Possibly, decision making processes must consider views from various disciplines such as planners, urban designers, engineers, architects and other related professionals such s sociologists who have knowledge on the human quality of life values necessary for long term satisfaction. To cite, it was found that more creative planning and design elements led to greater satisfaction among residents of Singapore's new town called Tampines (Seik, Yuen and Chin: 1999). Urban planning processes have to involve public participation in creating dream homes within a safe, secure and pleasant environment. Modern urban planning should aimed at improving the conditions and opportunities that urban environment can present wherever possible. Recall that, one of the overriding intentions of new town development is to humanise the urban environment by creating lively locations for a balanced settlement structure with residential areas and an urban diversity of shopping, services, recreational and cultural facilities. Another principle is to provide the best possible urban quality of life for every one to live, work and play.

According to Mercer's 2008 Quality of Living Survey, European cities dominate the worldwide rankings of locations with the best quality of living. Zurich retains its 2007 title as the highest ranked city, followed jointly by Vienna (2), Geneva (2), then Vancouver (4) and Auckland (5). Dublin has a worldwide rank of 25 and 8th place among European cities. On an annual basis Liverpool City Council consults with residents regarding a range of subjects, including satisfaction with council services, usage and awareness of leisure services, and general quality of life issues (Liverpool City Council: 2008).

On the whole, urban planning must respond to social change, demographic trends, economic efficiency, and also user needs. Quality of life should be the common goal of urban planning, more so of new town development (Schewenke: 1999). The physical means of progressing towards a better quality of life is intended by embracing the concept of sustainable development. Social improvements and well being are enhanced through co-operation between all the participants involved in urban planning and urban development with the commitment towards the quality of the total built environment experienced by urban dwellers.

\section{Quality of Life in Malaysia}

The government of Malaysia has attempted to provide a policy to keep pace with the rapid economic growth so as to bring about a better quality of life for the people (Mahathir: 1998). The Economic Planning Unit (EPU), in its report on the Malaysian Quality of Life Index (MQLI) 2002, defines quality of life as encompassing personal advances, a healthy lifestyle, access and freedom to pursue knowledge, and attaining a standard of living which surpasses the fulfillment of the basic and psychological needs of the individual, to achieve a level of social well being compatible with the nation's aspirations. The Malaysian Quality of Life Index (MQLI) is intended to be a comprehensive measure of welfare and human well-being, from a broader perspective which includes not only income but other aspects of life such as working life, family life, transport and communications, health, education, and public safety.

The Malaysian Quality of Life 2004 is the third report to describe the progress and for the first time examined the quality of life at the state level. The Malaysian quality of life, as measured by the Malaysian Quality of Life Index improved over the 1990-2004 period, increasing by 10.9 points. This improvement in the quality of life is also reflected in the achievement of all of the Millennium Development Goals ahead of the target date of 2015 (Fong Chan Onn: 2007). In year 2004 Malaysia has gone up 15 positions to rank $36^{\text {th }}$ among 101 countries in the New York Economist Intelligence Unit's quality of life index for 2005. As for Quality of Life 2008 ranking by International Living .Com, Malaysia was at $81^{\text {st }}$ place with the final score of 58 points among the 202 countries that were ranked. France leads the ranking with 85 points followed by Switzerland with 84 points, while Iraq is at the bottom rung with only 29 points. Singapore is in $79^{\text {th }}$ place. The determinant used by included cost of living, leisure and culture, economy, environment, freedom, health, infrastructure, risk and safety and climate.

The overall improvement in the economic development of the nation was also reflected in the increase in the quality of life of the population at the state level. This is attributed to various strategies at the federal and state levels. In line with this, the Ninth Malaysia Plan (2006-2010) sets out to achieve a stronger and more value-added economy, while giving substantial focus to socio-economic issues and uplifting the quality of life for all. The government remains committed towards improving the quality of life of all Malaysians said Deputy Prime Minister Datuk Seri Najib (2008). 


\section{New Town Development by State Economic Development Corporations}

The quality of life indicators have often been used by the community but have not been fully integrated into urban land use planning and new town development process. There is a need to encourage communities to create their own indicators to reflect their needs. This can contribute to the overall strategic direction for sustainable development to make sure the decision makers, town planners and developers know what is expected.

In Peninsular Malaysia, six State Economic Development Corporations for Selangor, Pulau Pinang, Perak, Johor, Pahang and Terengganu were involved in new town development. The emphasis on new town development varied between states. Each of the State Economic Development Corporations planned and developed its new towns so as to meet the policy requirement of the respective state government. There are thirteen new towns developed by six SEDCs including:

4.1 The Selangor State Economic Development Corporation was the most active with six new towns namely Shah Alam, Bangi, Kelana Jaya, Ampang Ulu/Klang, Bandar Sultan Suleiman and Kota Damansara. The new towns were to serve as catalysts for the regions and also to strike a balance between the Klang Valley and other areas in the state.

4.2 The Pulau Pinang Development Corporation developed three new towns, with Bayan Baru on the island, and Seberang Jaya and Batu Kawan on the mainland. These new towns were established to encourage the development of the surrounding areas.

4.3 The Perak State Economic Development Corporation developed its first new town called Seri Manjung with the objective of creating a balanced regional development, as well as achieving the New Economic Policy.

4.4 The Pahang State Economic Development Corporation developed Indera Mahkota as an important new town in the east coast of Peninsular Malaysia.

4.5 The Johor State Economic Development Corporation developed Pasir Gudang as the largest industrial new town in the southern part of the Peninsular.

4.6 The Terengganu State Economic Development Corporation developed Kerteh to cater for oil and gas industries.

\section{Aim and Objectives}

The aim of this research is to explore and assess the quality of life experienced by the residents of 13 new towns developed by the State Economic Development Corporations in Malaysia

The objectives are as follows:

(a) To identify the indicators of the quality of life in the new towns

(b) To compare and demonstrate the quality of life achieved in the 13 different living environments

\section{Research Methodology}

Data was gathered by self administered questionnaire. The questionnaire was validated by two senior town planners from the Federal Department of Town and Regional Planning, Malaysia and two senior lecturers from the Faculty of Architecture, Planning and Surveying, Universiti Teknologi MARA on the content validity. In order to identify the reliability of the questionnaire, it was pre-tested in a pilot study. The process involved 20 residents of Shah Alam New Town who work as lecturers in Universiti Teknologi MARA.

The questionnaire was divided into two parts. Part A contains the open-ended questions. In Part A the residents were asked to fill their personal profiles such as state of origin, reasons for staying, length of stay and, later asked to write the problems, suggestions or proposals for improvement. Part B consists of 22 closed-ended questions where respondents were required to indicate how they felt about their present stay using a five point scale. The questions were arranged on a single page for quick response by the residents. In order to get the equal chance on the resident participation, the total number of samples required were divided according to the ratio of different types of houses, namely low cost, medium cost and high cost in each new town as shown in Table 1. The questionnaire was distributed in an envelope with a cover letter and a self-addressed envelope of the researcher.

The total number of questionnaires distributed was 4,512. After waiting for about three months the number of respondents who returned the envelope was 436. The number of respondents is enough to meet the 95 per cent level of confident and the acceptable margin of error at five per cent suggested by Lewis (1985). Table 2 shows the distribution of respondents by new town. Data were analysed applying the Statistical Package for Social Science. Perceptual evaluation of the indicators was tabled to illustrate the quality of life dimensions. The ranking of the individual new town was calculated by multiplying the score on each dimension by the appropriate weighting. The same approach was applied to rank the indicators. 


\section{Analysis}

\subsection{Background of respondents}

Although these data were on general aspects, there were unique aspects of new towns environments that need to be determined and addressed. The results from 436 respondents to the survey questionnaire are discussed. Majority of the respondents were male which formed 69 per cent with a frequency of 301. This probably indicated that the principal or the head of the household family members responded to the questionnaire. The respondents were dominated by the active group with the largest group between 36-45 years old 33.5 per cent with a frequency of 146 out of 436 . The majority of the respondents which formed 51.6 per cent with a frequency of 225 were staying due to employment. This figure implied that there were employment opportunities created in new towns or in the surrounding areas. The largest group of them (51 per cent) did not work in there but working outside the new towns. About 40 per cent of the respondents were employed by the private sectors and the research found that they were engaged in administrative and managerial work. In terms of respondents' home, the majority of them, or 65 per cent, reported that they owned their homes and 61 per cent of these houses were medium cost type. It was found that the most frequently owned homes were the single storey houses.

\subsection{Problems faced and suggestions by respondents}

The question on the problems faced in the new towns was an open-ended item. Respondents were required to write down the problems experienced in the particular area. A similar type of question asked for the suggestion for an improvement of their living environment. The open-ended questions were intended to gather as much as possible the related answers from respondents. There was a variety of problems listed, however, for the analysis they were grouped so as to have the general assessment for all new towns.

The survey showed that the largest group of respondents ( 23 per cent) had no problem staying in the new towns. Others with problems including 20 per cent public facilities, 11 per cent social, 11 per cent environment, 9 per cent transportation, 7 per cent economic and 6 per cent safety.. This shows that the majority of residents of the new towns developed by the States Economic Development Corporations are living in a satisfactory environment. As for the suggestions, the largest group of them ( 24 per cent) requested for the improvement in the public facilities where some stated the need for bigger schools and more classrooms to accommodate the population. About 19 per cent did not answer this question. Other suggestions include 11 per cent for social improvement, 9 per cent for environment, 7 per cent for transportation and 5 per cent for safety.

\subsection{Residents' Perceptions}

In this part, the analysis is focused on Section B of the original survey questionnaire which retrieved information on the residents' perceptions. This is concerning the community facilities, infrastructure services, commercial facilities open space and surrounding areas, feeling safe in the living area and safety of property, feeling about living in the particular new town, sense of neighbourhood community, adequate comfort in housing, house price or rental value, and mobility and public transportation service. Their perceptions are assumed to be an important indicator for a particular new town being an ideal or unsatisfactory place to live. The residents had freedom to make choices regarding their own living environment. The residential environment is important in the analysis of quality of life because of the role it plays in human experience. The objective of this research was to identify the quality of life in new town developments.

The research attempts to measure the effect of new town environment on the residents' life and to compare the quality of life achieved in all the 13 new towns. The findings from residents' perceptions may become one of the ways for getting people involved in ensuring the continued success of their community. The survey questionnaire asked whether the respondent's perceptions were completely satisfactory, satisfactory, average, unsatisfactory and completely unsatisfactory to quantify their living environments' quality. The quality of life would increasingly play a significant role in various planning dimensions and would likely to a complex one (Dissart and Delier: 2000).

Table 3 shows the overall findings on respondents' perceptions towards the list of variables. In some cases the variables were grouped together based on their characteristics and functions. There were ten groups to summarised the indicators used in the survey. The average percentage was according to the satisfaction level for the particular group.

There were five variables listed as community facilities namely Primary School, Secondary School, Higher Learning Centre, Place of Worship and Entertainment Centre. The average percentage for community facilities was 31.7 per cent with satisfaction level of satisfactory. However, among five community facilities listed, places of worship were rated as completely satisfactory, while higher learning centres and entertainment centres were of average satisfaction level.

Both primary school and secondary school were at satisfaction level of satisfactory in the State Economic Development Corporations' new towns development. Referring to shopping facilities, the average was at the satisfactory level though the centre for higher order goods was at the level of average. As for infrastructure services, these were also at the satisfactory level, but only electricity services was found to achieve the level of completely satisfaction. The 
environment and open space was rated average, with all the elements including esthetic, cleanliness, open space and children's playground were rated with the same satisfaction level by majority of respondents.

The next group titled safety of self and properties was also at the satisfactory level of average. However, majority of respondents were satisfied about the safety of self and properties as compared to traffic safety. The respondents were satisfied about living in the new town, sense of community and comfortable space in the house. House price and rental was of average satisfaction level. As for mobility and public transportation facilities the average satisfaction level was satisfactory. However, rail service had the highest percentage of completely dissatisfied responses while bus services and taxi services were at the level of average.

The summary of findings shows that only places of worship and electricity services achieved the satisfaction level of completely satisfied while only rail services was rated as completely dissatisfied. However, referring to the ten groups in Table 3, overall none of them achieved the completely satisfied level, eight were rated as satisfied, the other two as average and none was rated as dissatisfied or completely dissatisfied. The research showed that from the indicators used in the analysis it can deduced that new towns developed by the State Economic Development Corporations were generally accepted by the residents as providing satisfying living environment.

\subsection{Respondents' Quality of Life by New Towns}

The purpose of this section is to elaborate on the majority of respondents' level of satisfaction by percentage on the quality of all the 13 new towns. Each of these new towns was compared to each other by means of the 22 variables of their residential environment, which were related to their satisfaction as well as to the characteristics of the social environment. The variables were assessed by the respondents from the $13 \mathrm{new}$ towns were rated. For the purpose of this research, an important outcome is satisfaction with the 22 listed variables as an indirect indication of the general outcome of quality of life in these new towns. The majority of respondents being satisfied with those variables is important because it demonstrated the ability of the physical design and planning for a particular new town to fulfill the expectations of the community.

The discussion began with the highest score new town which was Ampang/Ulu Klang based on the weight given. For every variable, a mark was given based on the highest percentage of satisfaction level from respondents' perceptions for each new town. The satisfaction levels were given weight to enable comparison on the score among the new towns. The weight given was ' 5 ' for completely satisfied, ' 4 ' for satisfied, ' 3 ' for average, ' 2 ' for dissatisfied and ' 1 ' for completely dissatisfied. The scoring weight for each item therefore was reversed and the total score was based on the sum of all the weightings for each new town. Then each of the variables was examined and a weighting was given for evaluation and comparison purposes. The maximum score for each new town was 110 . Measuring the quality of life in towns was by giving weight to each variable and adding to weights assigned to other variables for the particular area. The total score provided an overall ranking for the area and was intended to represent its overall quality. The areas were then rank ordered. Similar approaches have been used for other cities (Marans and Couper, 20001; Brown, 1999). Based on the above statement, the same principle was applied in this analysis. After all the lists of variables were completed, the weight for each new town was totaled up.

The results demonstrated the ranking of the 13 new towns. Ampang/Ulu Klang scored the highest score of 90, followed by Kelana Jaya with 87 . Shah Alam, Bayan Baru and Pasir Gudang were in the third place having scored 82. Bangi together with Indera Mahkota scored 81 points on fourth place. Seri Manjung the fifth place with 78 points. Seberang Jaya on sixth place with 75 points, Kota Damansara was in seventh place with a total points of 74 while Batu Kawan was in eighth position with 71 points. Bandar Baru Sultan Suleiman was in ninth position with 70 points. Kerteh in Terengganu was in the last position with 65 points.

It was found that there was a difference of 25 points between Ampang/Ulu Klang which was top of the list compared to Kerteh in the last place of the 13 State Economic Development Corporations new towns studied. Each of these new towns was listed in the order of Ampang /Ulu Klang with the best quality of life and ended with Kerteh having the poorest quality of life to compare the achieved satisfaction levels responded by the largest group of the survey respondents.

\section{Conclusion}

The role of the State Economic Development Corporations in new town development appeared to vary and the results of the residents' perceptions survey were able to demonstrate the quality of life of each new town. These findings indicated that there was a relationship between the physical characteristics and the quality of life in new town development. These new towns were ranked based on the score points from the survey analysis. Kelana Jaya and Ampang/Ulu Klang had achieved the status of 99 per cent completion and these two new towns were ranked at the top of the list based on the analysis of the survey. The same relationship was also reflected in the findings for Kerteh which was the smallest size, with a population far below the minimum requirement, and had been ranked last with the lowest score. 
The ranking of the new towns was as follows:

\section{Ampang/Ulu Klang}

2. Kelana Jaya

3. Shah Alam, Bayan Baru and Pasir Gudang

4. Bangi and Indera Mahkota

5. Seri Manjung

6. Seberang Jaya

7. Kota Damansara

8. Batu Kawan

9. Bandar Baru Sultan Suleiman

10. Kerteh

The research was also able to rank all the 22 variables based on the residents' perceptions so as to demonstrate the comparison between them.

The result was as shown in the following list:

1. Religious centres

2. Electricity supply

3. Telephone service

4. Primary schools

5. Water supply

6. Commercial service for lower order goods

7. Secondary schools; Mobility to work place

8. Feelings about living in new towns; Sense of neighbourhood

9. Feeling safe and safety of property; Adequate comfort in housing

10. Beauty of the surrounding area; Cleanliness; Traffic safety; Bus services

11. House price/ rental value

12. Open space facilities

13. Children's playgrounds

14. Entertainment centres

15. Taxi services

16. Commercial services for higher order goods

Among the 22 variables the research found that religious centres were to be the most well provided facilities in the State Economic Development Corporations' new towns with the highest score. All new towns studied were also well served by infrastructure facilities including electricity, telephone service and also water supply and had achieved high satisfaction responses from the residents. However, surprisingly, primary school facilities were ranked as number four which was lower than the religious centres, electricity service and telephone service. The young working age of the respondents who formed the majority of the residents of these new towns were assumed to have children of primary school age and they felt that the primary school requirements needed to be improved. Commercial service centres for lower goods were ranked as number six. However, commercial service centres for higher order goods were ranked second last in the list. This reflected the fact that the development of these new towns was focused on the provision of the basic commercial centres for the communities.

\section{References}

Brown, D. (1999). Using Person-Environment Perspectives as a Measure of the Quality of Life in Formal and Informal Settlements: A Case Study from Trinidad, in Yuan, Yuen \& Low, (eds.) Urban Quality of Life, Critical Issues and Options, National University of Singapore.

Campbell, A., Converse, P., \& Rodgers, W. (1976). The Quality of American Life, New York: Sage.

Cullingworth, J. B. and V. Nadin. (2006). Town and Country Planning in the UK, 14th Edition, Routledge, Madison. 
Danang Priatmodjo. (1997). Urban Sprawl in Jabotek: Agglomeration of New Towns, Conference on The Challenge of Urbanisation: Socio-cultural and Spatial Transformation, Semarang, Indonesia.

Dasimah Bt Omar. (2008). Development Strategy and Physical Characteristics of New Towns in Malaysia, Asian Social Science, Canadian Centre of Science and Education, Vol. 4 No. 9.

Dasimah Bt Omar. (2008). Planning Principles and Control Mechanisms of New Town Development in Malaysia, Asian Social Science, Canadian Centre of Science and Education, Vol.4 No. 9.

Dissart, J.C. \& Deller, S.C. (2000). Quality of Life in the Planning Literature, Journal of Planning Literature (FJPL), Vol. 15 Iss. 1 Aug. 2000.

Fong Chan Onn. (2007). Statement by Honourable Datuk Seri Dr Fong Chan Onn, Minister of Human Resources, Malaysia ASPAG Ministerial Meeting ILC 96, 13 June 2007, Geneva.

Giulietta Fadda and Paola Jirón. (1999). Environment\&Urbanization Vol 11 No 2 October 1999.

Government of Malaysia. (2005). Malaysian Quality of Life 2004.

Government of Malaysia. (2005). Ninth Malaysia Plan, 2006-2010.

Hall, P. (2002). Urban and Regional Planning, Routledge, Madison.

Julie Brown and Dinah Gardner. (2002). Hong Kong and Macau, Rough Guides, Hong Kong.

Leitmann, J. (1999). Can City QOL Indicators be Objective and Relevant? Towards a Tool for a Sustaining Urban Development, in Yuan, Yuen \& Low, (eds.) Urban Quality of Life, Critical Issues and Options, National University of Singapore.

Lewis, R. C. (1985). Getting the Most from the Marketing Research, Part V; Predicting Hotel Choice; The Factors Underlying Perception: The Cornell H.R.A. Quarterly, Feb. 1985, 83-99.

Liverpool City Council. (2008). Quality of Life Survey 2008 Prepared by: Jenna Allen Produced by BMG Research.

Mahathir B. Mohamad. (1998). The Way Forward, London: Weidnfeld \& Nicolson.

Marans, W.R. and Couper, M. (2000). Measuring the Quality of Community Life: A Program for Longitudinal and Comparative International Research, Quality of Life in Cities, $21^{\text {st }}$ Century QOL, The Second International Conference, March 2000, Singapore.

Milbrath, L.W. (1978). Indiators of environmental quality" in UNESCO, "Indicators of environmental quality and quality of life", reports and papers in Social Sciences No.38, pages 3-56.

Morris, E.S. (1997). British Town Planning and Urban Design: Principles \& Policies, Edinburgh: Longman.

Nancy Kleniewski. (2005). Cities and Society, Wiley, Blackwell.

Philip Berke, David R. Godschalk and Edward J. Kaiser, (2006). Urban Land Use Planning, University of Illinois Press.

Schwenke, S. (1999). Justifying Urban Quality: An Ethics Approach, Yuan, Yuen \& Low, (eds.) in Urban Quality of Life, Critical Issues and Options, National University of Singapore.

Seik, F. T.; Yuen, B. and Chin, L. (1999). Studies on Quality of Life of Singaporeans, Yuan, Yuen \& Low, (eds.) in Urban Quality of Life, Critical Issues and Options, National University of Singapore. 
Table 1. Distribution of Sample on Residents' Perceptions Survey by Study Area at 95 \% Confidence Limit.

\begin{tabular}{|c|c|c|c|c|c|c|c|c|}
\hline \multirow[b]{2}{*}{ STATE } & \multirow[b]{2}{*}{ NEW TOWN } & \multicolumn{2}{|c|}{ LOW COST } & \multicolumn{2}{|c|}{ MEDIUM COST } & \multicolumn{3}{|c|}{ HIGH COST } \\
\hline & & UNITS & $\begin{array}{l}\text { NO. OF } \\
\text { SAMPLE }\end{array}$ & UNITS & $\begin{array}{l}\text { NO. OF } \\
\text { SAMPLE }\end{array}$ & UNITS & $\begin{array}{l}\text { NO. OF } \\
\text { SAMPLE }\end{array}$ & TOTAL \\
\hline \multirow{6}{*}{ SELANGOR } & Shah Alam & 6,395 & 69 & 25,113 & 261 & 6,672 & 66 & 38,180 \\
\hline & Bangi & 1,250 & 53 & 6,251 & 264 & 1,574 & 67 & 9,075 \\
\hline & Kelana Jaya & 544 & 31 & 4,924 & 282 & 1,103 & 63 & 6,571 \\
\hline & Ampang/Ulu Klang & 2,672 & 130 & 4,896 & 237 & 265 & 13 & 7,833 \\
\hline & $\begin{array}{l}\text { Bandar Baru Sultan } \\
\text { Suleiman }\end{array}$ & 3,340 & 356 & - & - & - & - & 3,340 \\
\hline & Kota Damansara & 900 & 114 & 1,812 & 230 & 44 & 6 & 2,756 \\
\hline \multirow[t]{3}{*}{$\begin{array}{l}\text { PULAU } \\
\text { PINANG }\end{array}$} & Bayan Baru & 1,779 & 65 & 7,650 & 279 & 1,149 & 42 & 10,578 \\
\hline & Seberang Jaya & 2,091 & 115 & 4,140 & 228 & 599 & 34 & 6,830 \\
\hline & Batu Kawan & 395 & 156 & 216 & 85 & - & - & 611 \\
\hline JOHOR & Pasir Gudang & 7,528 & 254 & 3,274 & 110 & 651 & 22 & 11,453 \\
\hline PERAK & Seri Manjung & 989 & 71 & 2,785 & 199 & 1,437 & 103 & 5,211 \\
\hline $\begin{array}{l}\text { TERENGG } \\
\text { ANU }\end{array}$ & Kerteh & - & - & 192 & 130 & - & - & 192 \\
\hline PAHANG & Indera Mahkota & 2,114 & 116 & 2,793 & 154 & 1,940 & 107 & 6,847 \\
\hline \multicolumn{2}{|l|}{ TOTAL } & 29,997 & 1,530 & 64,046 & 2,459 & 15,434 & 532 & 109,477 \\
\hline
\end{tabular}

Table 2. Distribution of Respondents on Residents' Perceptions Survey.

\begin{tabular}{|c|c|c|c|c|}
\hline STATE & NEW TOWN & $\begin{array}{l}\text { NO OF } \\
\text { SAMPLES } \\
\text { DISTRIBUTED }\end{array}$ & $\begin{array}{l}\text { NO } \\
\text { RESPONDENTS }\end{array}$ & $\begin{array}{l}\text { PERCENTAGE } \\
\text { OF } \\
\text { RESPONDENTS }\end{array}$ \\
\hline \multirow{6}{*}{ SELANGOR } & Shah Alam & 396 & 49 & 11.2 \\
\hline & Bangi & 384 & 62 & 14.2 \\
\hline & Kelana Jaya & 376 & 30 & 6.9 \\
\hline & Ampang/Ulu Klang & 380 & 49 & 11.2 \\
\hline & Bandar Baru Sultan Suleiman & 356 & 16 & 3.7 \\
\hline & Kota Damansara & 350 & 33 & 7.6 \\
\hline \multirow[t]{3}{*}{ PULAU PINANG } & Bayan Baru & 386 & 35 & 8.0 \\
\hline & Seberang Jaya & 377 & 17 & 3.9 \\
\hline & Batu Kawan & 241 & 8 & 1.8 \\
\hline JOHOR & Pasir Gudang & 386 & 11 & 2.5 \\
\hline PERAK & Seri Manjung & 373 & 55 & 12.6 \\
\hline TERENGGANU & Kerteh & 130 & 8 & 1.8 \\
\hline PAHANG & Indera Mahkota & 377 & 63 & 14.4 \\
\hline \multicolumn{2}{|l|}{ TOTAL } & 4,512 & 436 & 100.00 \\
\hline
\end{tabular}


Table 3. Overall Findings on Residents' Perception Survey

\begin{tabular}{|c|c|c|c|c|c|}
\hline Satisfaction Level (\%) & $\begin{array}{l}\text { Completely } \\
\text { Satisfied }\end{array}$ & Satisfied & Average & Dissatisfied & $\begin{array}{l}\text { Completely } \\
\text { Dissatisfied }\end{array}$ \\
\hline Community Facilities & & & & & \\
\hline Primary Schools & 34.6 & 48.4 & 12.6 & 2.3 & 1.4 \\
\hline Secondary Schools & 26.1 & 40.6 & 17.2 & 4.4 & 5.5 \\
\hline Place of Worships & 48.9 & 33.3 & 8.3 & 3.9 & 3.0 \\
\hline Entertainments Centers & 2.1 & 14.7 & 37.4 & 18.8 & 10.8 \\
\hline Shopping Facilities & & & & & \\
\hline Centre for higher order goods & 8.5 & 18.8 & 31.2 & 18.6 & 17.6 \\
\hline Centre for lower order goods & 23.6 & 39.4 & 25.7 & 8.5 & 2.3 \\
\hline Infrastructure Services & & & & & \\
\hline Electricity & 45.6 & 45.0 & 7.6 & 1.6 & 0.2 \\
\hline Water & 40.4 & 41.7 & 13.3 & 3.4 & 1.1 \\
\hline Telecommunications & 37.4 & 42.2 & 12.8 & 3.2 & 3.4 \\
\hline Environment \& open spaces & & & & & \\
\hline Aesthetic of the area & 8.0 & 33.5 & 40.6 & 12.6 & 5.0 \\
\hline Cleanliness of the area & 4.1 & 33.0 & 40.1 & 15.6 & 6.4 \\
\hline Open space & 14.0 & 24.0 & 32.8 & 16.5 & 11.5 \\
\hline Children's playground & 10.3 & 23.2 & 31.0 & 20.0 & 13.5 \\
\hline Safety of self and Properties & & & & & \\
\hline Self and property & 6.2 & 38.8 & 35.3 & 14.9 & 4.8 \\
\hline Traffic safety & 3.4 & 33.9 & 40.4 & 16.1 & 5.7 \\
\hline $\begin{array}{l}\text { Feeling about living in the } \\
\text { area }\end{array}$ & 24.1 & 46.8 & 22.2 & 3.9 & 2.3 \\
\hline Sense of Community & 13.1 & 40.8 & 31.7 & 9.6 & 4.1 \\
\hline $\begin{array}{l}\text { Comfortable space in the } \\
\text { house }\end{array}$ & 12.6 & 41.3 & 33.5 & 8.3 & 4.1 \\
\hline House price/ rental value & 4.4 & 28.7 & 42.2 & 14.0 & 6.9 \\
\hline Mobility \& Public Transport & & & & & \\
\hline Mobility to work & 12.8 & 44.7 & 26.8 & 10.6 & 2.3 \\
\hline Bus services & 10.1 & 29.6 & 30.0 & 17.9 & 11.0 \\
\hline Taxi services & 7.6 & 25.5 & 31.4 & 21.8 & 12.2 \\
\hline
\end{tabular}

